\title{
Observation on Marine Copepod - Appendicularian Naturally Changing Concentrations Along Southwest Coast of India
}

\author{
Jean J.JOSE ${ }^{1 *}$, Aaron P. LIPTON ${ }^{2}$, Lincy ALEX ${ }^{3}$, Purayath UDAYAKUMAR ${ }^{1}$, \\ Bhama R. RAJESH ${ }^{4}$, Mary Teresa P.MIRANDA $^{4}$ \\ ${ }^{1}$ Centre for Earth Science Studies, Marine Biology and Chemistry Laboratory, Chemical Sciences Division, \\ Thiruvananthapuram-695031, Kerala, India; jeanlincy@gmail.com ( ${ }^{*}$ corresponding author) \\ ${ }^{2}$ Central Marine Fisheries Research Institute, Marine Biotechnology Laboratory, Vizhinjam- 695 521, Kerala, India \\ ${ }^{3}$ St. Gregorios College, Department of Zoology, Kottarakkara - 691531, Kerala, India \\ ${ }^{4}$ Fatima Mata National College, Marine Biology Laboratory, Department of Zoology, Kollam - 691001, Kerala, India
}

\begin{abstract}
Patterns of copepod - appendicularian distribution were studied along the Mangalore coastal waters (12 $\left.50^{\prime} 49^{\prime \prime} \mathrm{N} ; 74^{\circ} 48^{\prime} 50^{\prime \prime} \mathrm{E}\right)$ of the Arabian Sea to understand the food and feeding relationship existing among these groups. Sampling was conducted during premonsoon, monsoon and post-monsoon extending from January 2009 to December 2010. The copepod and appendicularian community was sampled with a $60 \mu \mathrm{m}$ net to include the smallest species and their developmental stages. Copepod biomass, especially calanoids, was substantially high throughout the study. Seasonal mean results showed that the small-sized copepods (calanoids, harpacticoida and cyclopoids) dominated in terms of biomass and production. Calanoids found in abundance included Acartia, Centropages, Calanus, Eucalanus and Labidocera. Cyclopoid and Harpacticoid copepods genera dominated included Oithona, Oncaea and Microsetella, Macrosetella. Appendicularian species diversity was represented by Oikopleura fusiformis, O. dioica and its juveniles represented as Oikopleura sp. Total chlorophyll (chlorophyll $a$ ) ranging between 10 and $20 \mathrm{mg} \mathrm{m}^{-3}$ indicated the eutrophic state as well as productivity prevailing during the study period. Principal component analysis (PCA) indicated the routine and opportunistic seasonal grazers and establishes a phytoplankton - appendicularia - copepod - fish food chain relationship along Mangalore coast.
\end{abstract}

Keywords: appendicularia, biological production, copepods, ecological association, environmental factors, Mangalore coast, natural population

Abbrevations: Chlorophyll a: Total chlorophyll, PCA: Principal Component Analysis, PC: Principal Component, SSC: Suspended Sediment Concentration, Mangalore: $\mathrm{Ml}, \mathrm{NO}_{3}$ : Nitrate-N, $\mathrm{NO}_{2}$ : Nitrite-N, $\mathrm{NH}_{4}^{+}$: Ammonia, $\mathrm{PO}_{4}-\mathrm{P}$ : Inorganic Phosphate, SiO $-\mathrm{Si}$ : Inorganic silicate, DO: Dissolved oxygen, CAS: Centre for Advanced Studies, SPSS: Statistical Package for Social Science

\section{Introduction}

Variations of environmental factors caused by atmospheric forcing have led to fundamental differences in the pelagic marine ecosystem in terms of production (DuffyAnderson et al., 2005; Piatt et al., 1996). While comprising a small portion of the surface area, the continental margins account more than $50 \%$ of primary productivity in the oceans (Jahnke and Shimmield, 1995). Coastal upwelling plays an important role in biological productivity and carbon cycling within oceans. The west coast of India (Arabian Sea) is a region of intense upwelling associated with southwest monsoon (May to September) whereas the east coast experiences only a weak upwelling associated with the northeast monsoon (October to January), resulting in marked differences in hydrographic regimes, productivity patterns and qualitative and quantitative composition of fisheries (Venkataraman and Wafar, 2005). Productivity reasons explicated by the researchers concentrated in this region include the inflow of a network of rivers, backwaters, rocky shores and the intense upwelling associated with southwest monsoon influenced upon the improved nutrient composition (Madhupratap et al., 2001). The upwelling along Mangalore coast is considered as one of the major upwellings along the southwest Indian coast. The resultant high production is attributed not only due to the fertilization of surface waters by nutrients transported from depth during upwelling (Harnstrom et al., 2009), but also due to the inflow of organic rich effluents from industrial, urbanization, anthropogenic, port and fishing activities through the river network (Udayakumar et al., 2009).

As in coastal and oceanic areas, microbially dominated food webs of continental margins enhance carbon retention in surface waters, while zooplankton activities enhance carbon export by algal grazing and production of 
sinking faeces (Peinert et al., 1989). Zooplankton groups are biological indicators of water quality, eutrophication and pollution levels by the abundance or absence of specific representatives and are important sources of food chain (Sibel, 2006). Predation by omnivorous copepods on other components of the phytoplankton and microzooplankton, especially small heterotrophic nanoflagellates and ciliates, may be important. The fate of primary production in the Mangalore upwelling system has been attributed to herbivore by the abundant copepods (Verlecar et al., 2006). It is well known that copepods feed mostly on phytoplankton, mainly the diatoms. However, trophic coupling between copepods and appendicularians has not yet been thoroughly examined in this region.

For a few coastal areas, it has been suggested that protists occasionally constitute the main food source for calanoid and cyclopoid copepods (Kleppel et al., 1991; Levinsen et al., 2000; Pierce and Turner, 1992), which would have important implications for food web dynamics. The sparse information on this group in the coastal upwelling area of southwest Indian coast makes it difficult to assess the quantitative and ecological importance of appendicularians in this ecosystem and to determine their position and also their influence on food-web dynamics. In addition, no information is available on the feeding rates of either dominant copepods or appendicularians on microprotozoans and bacteria, nor on the factors regulating their feeding in the southwest Indian coastal ecosystems; this precludes any speculations about their potential role in the pelagic food web. In order to provide an insight into this, the present study was aimed to attempt statistically the feeding of small copepods on the full food size-spectrum (phytoplankton) and predation on juvenile appendicularians.

\section{Materials and methods}

\section{Field sampling and Study area}

Water sampling, in situ analysis and filtration process for chlorophyll $a$ estimation were conducted onboard during the different cruises of a private owned purse seiner of Mangalore from January 2009 to December 2010, at different seasons (pre-monsoon, monsoon and post-monsoon). Sampling point along M1 (12 $50^{\prime} 49^{\prime \prime} \mathrm{N} ; 74^{\circ} 48^{\prime} 50^{\prime \prime}$ E) was located from bar mouth towards sea at a distance of $1.0 \mathrm{Km}$ (Fig. 1). This point was selected on the basis of high feeding intensity and abundance of copepods and appendicularians diversity as understood from the previous four year's data on coastal pollution monitoring survey conducted at $0.5,1.0,3.0,5.0$ and $10.0 \mathrm{~km}$ distance from shore region along Mangalore coast. Samples were collected from this transect off Mangalore.

\section{Sampling protocol}

Surface chlorophyll a concentration was determined using Whatman $47 \mathrm{~mm} \varnothing \mathrm{GF} / \mathrm{C}$ fiber $(0.7 \mu \mathrm{m}$ nominal pore size). The contents were extracted in $90 \%$ acetone, centrifuged, refrigerated in dark for 20 to $24 \mathrm{~h}$ and the light absorbance at 750, 664, 647 and $630 \mathrm{~nm}$ was recorded in a Shimadzu UV 1800 spectrophotometer, as per Strictland and Parsons (1972). Hydrographical parameters such as salinity (psu) and $\mathrm{pH}$ were measured in situ using probes (WTW Multi Line P4). Values of SSC were determined as the weight of material retained on a GF/F membrane per volume unit after drying the filter for $2 \mathrm{~h}$ at $120^{\circ} \mathrm{C}$. The chemical fixing of dissolved oxygen was done onboard by the modified Winkler's method and later analyzed in the laboratory. $\mathrm{NO}_{3}, \mathrm{NO}_{2}, \mathrm{NH}_{4}^{+}, \mathrm{PO}_{4}-\mathrm{P}, \mathrm{SiO}_{4}-\mathrm{Si}$ in filtered samples and Total Nitrogen, Total Phosphorus in unfiltered samples were analyzed spectrophotometrically (Grasshoff, 1999).

The zooplankton collection was done by horizontal hauling using a Bongo net (mouth diameter $40 \mathrm{~cm}$, mesh size: $60 \mu \mathrm{m}$ ) equipped with a calibrated flow meter (General Oceanics, Model-2030) to quantify the volume of water filtered. The net was operated from the deck of the purse seiner for 10 minutes at a speed of 2 knots/hour. Concentrated zooplankton was preserved in $4.0 \%$ formaldehyde and seawater solution, immediately after collection. Identification of the copepod specimens was performed according to Kasturirangan (1963) and copepodids (up to genus level) was carried out as described by Paffenhofer (1998). Appendicularians identification was confirmed from the CAS in Marine Biology, Annamalai University, India. A phase contrast microscope (Olympus CX 41) was used to count and identify the zooplankton taxa. Some groups of

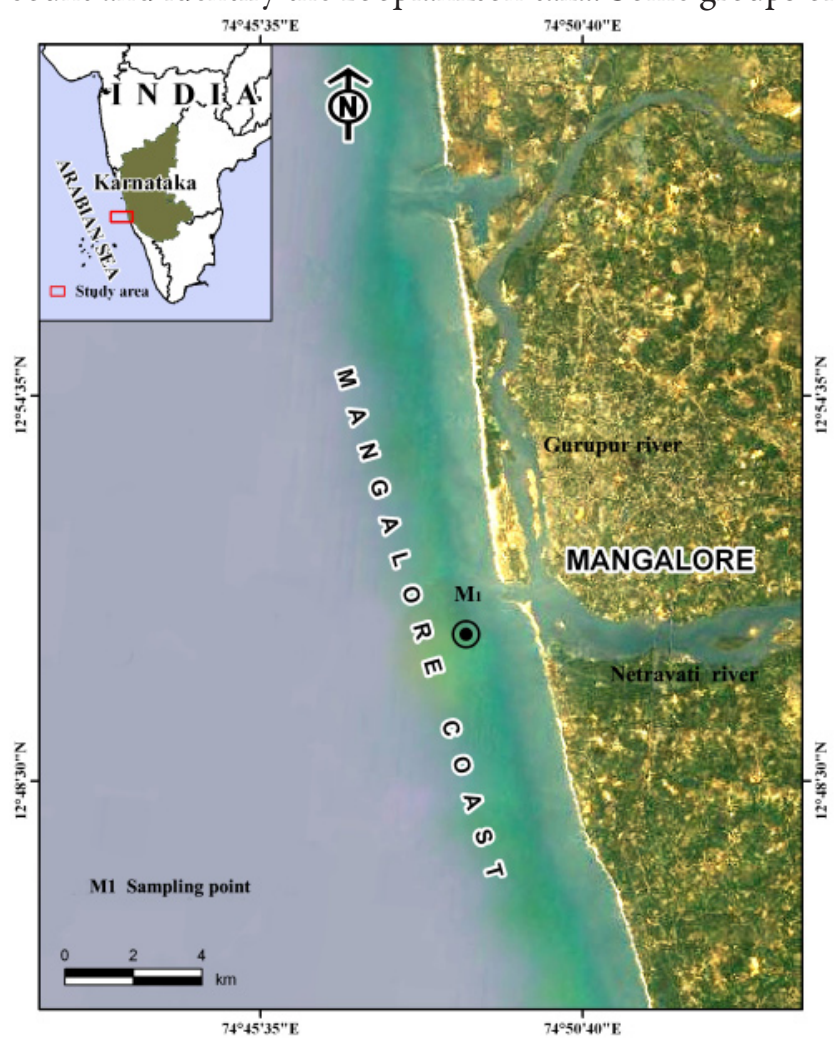

Fig. 1. Map of the Mangalore coast with sampling point 
22

organisms other than copepods and appendicularians that appeared in the zooplankton samples were not taken in to account in the calculations of the zooplankton diversities, since the sampling methodology was not suitable for estimating their abundance correctly.

\section{Statistical analysis}

PCA was used to investigate the statistical significance between seasons based on the relationship of copepods to appendicularians using SPSS 16 Version.

\section{Results and discussion}

Coastal waters of Mangalore were reported to be enriched by nutrient irrespective of seasons, mainly from domestic sewages and organic effluents from the major and minor industries situated on the riverbanks, fish landing centers and harbor operations through the two rivers viz., Gurupur and Netravati (Verlecar et al., 2006). One of the major findings emanating from the results of the present study is that the riverine fresh water fluxes interacted closely with coastal waters through tide movement and mixing. The fresh water inflow from the rivers Netravati and Gurupur widely influenced the nutrient characteristics of the coastal waters. The physico chemical characteristic of the study area is given in Fig. 2. Chlorophyll $a$ was relatively high, with a mean value of $19.08 \mathrm{mg} \mathrm{m}^{-3}$ during the post-monsoon season. Two year seasonal mean value of chlorophyll was $14.11 \mathrm{mg} \mathrm{m}^{-3}$. This clearly predicts the trophic state of M1 as eutrophic during the study period (from 2009 January to 2010 December). The chlorophyll a content during the study period ranged from 11.37 to $19.08 \mathrm{mg} \mathrm{m}^{-3}$ indicating the enhanced primary production level of the coastal waters. However, it indicated the eutrophic state prevailing and the enhanced productivity routed through natural upwelling processes along Mangalore coast. An earlier appraisal along this region also suggested similar variations in different factors due to upwelling and freshwater input (Harnstron et al., 2009). Salinity was almost steady for the pre-monsoon and monsoon period (mean value of 31.40 and $34.10 \mathrm{psu}$ ), but a marked variation was noted during the post-monsoon (mean value of 23.60) due to influx of fresh water. DO was ranging from 4.5 to $5.5 \mathrm{mg} \mathrm{L}^{-1}$ and the ammonia content had a sharp increase during pre-monsoon and monsoon seasons with a

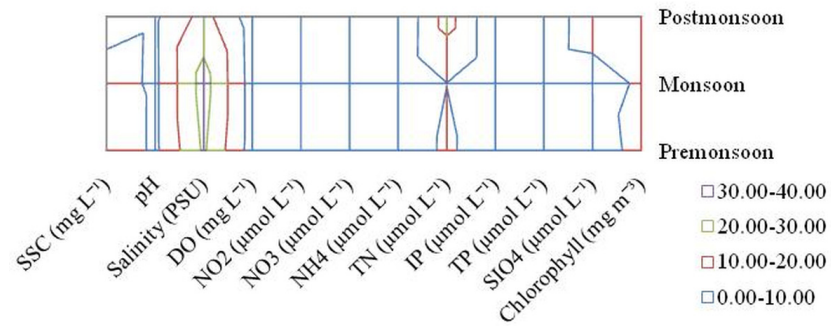

Fig. 2. Hydrochemical characteristics along Mangalore coast during different seasons two year seasonal average of $0.48 \mu \mathrm{mol} \mathrm{L}^{-1}$. Other nutrient factors such as $\mathrm{NO}_{3}, \mathrm{NO}_{2}$ showed an increasing trend during pre-monsoon. However, the $\mathrm{SiO}_{4}-\mathrm{Si}$ varied maximum during post-monsoon with an average value of $17.40 \mu \mathrm{mol}$ $\mathrm{L}^{-1}$, though the mean value during the entire study period was $9.76 \mu \mathrm{mol} \mathrm{L}^{-1}$. The SSC showed wide fluctuation seasonally with a high value of $18.8 \mu \mathrm{mol} \mathrm{L}^{-1}$ at pre-monsoon, while it was $15.27 \mu \mathrm{mol} \mathrm{L}^{-1}$ during monsoon season. Phosphorus, the limiting nutrient for phytoplankton production, varied moderately and its factors analyzed viz, $\mathrm{PO}_{4}-\mathrm{P}$, total phosphorus showed a marked variation in monsoon and post-monsoon (average 1.12; $1.93 \mu \mathrm{mol} \mathrm{L}^{-1}$ ) and was almost steady for these two seasons.

Calanoid copepods of genus Acartia, Centropages, Calanus, Eucalanus and Labidocera showed maximum abundance during the period of observation. This was followed by cyclopoids and harpacticoids represented by the genera Oithona, Oncaea and Microsetella, Macrosetella respectively. Copepods play a flexible role in the marine pelagic food web as secondary or tertiary consumers that show their omnivory depending on the phytoplankton availability and are also able to feed on the eggs and nauplii of other copepods (Ohman and Hirche, 2001). Appendicularian species found in majority was Oikopleura fusiformis and O. dioica. The juveniles (60 to $80 \mu \mathrm{m}$ size) were recorded as Oikopleura sp. Appendicularians are one of the mesozooplankton groups in marine ecosystems, which grow in a faster magnitude than copepods and mostly outnumbering their population (Vargas et al., 2002). The species diversity of zooplankton is given in Fig. 3 a, b, c. The copepodids showing abundance throughout the study included: Acartia, Centropages and Oithona, in the order of abundance. Adult species composition of appendicularians pooled was in a size range of 0.5 to $2.0 \mathrm{~mm}$. The maximum species diversity of copepods was noted during the monsoon season (Fig. 3 b). Others were opportunistic invaders with respect to seasons and grazing pressure. They included: A. danae, A. erythreae, Calanopia minor, Paracalanus parvus, Nanocalanus minor, Eucalanus elongates, Temora turbinate and $T$. discaudata among calanoids. Cyclopoids and harpacticoid groups were recorded by single species viz, Oncaea venusta and Macrosetella gracilis. Juvenile stages of appendicularians were at maximum during pre-monsoon and monsoon, while the adult stages dominated during monsoon and post-monsoon. Copepodid stages of calanoids Acartia, Centropages showed high abundance during pre-monsoon and monsoon, indicating its peak breeding periods along M1. During the same period, the cyclopoid genus, Oithona copepodid also had its maximum counts, signifying its breeding condition during these seasons. Most of the adult cyclopoids recorded during these periods were egg bearers.

In order to preserve the robustness of analysis, the seasonal zooplankton diversity was examined using PCA and the data is presented in Tab. 1 and 2. In general, component matrix correlation coefficients which are greater than 
Tab. 1. Component matrix extracted using PCA for zooplankton species diversity at Mangalore

\begin{tabular}{ccc}
\hline \multicolumn{3}{c}{ Component Matrix } \\
\hline & \multicolumn{2}{c}{ Component } \\
\cline { 2 - 3 } & PC1 & PC2 \\
\hline Centropages furcatus & 0.887 & 0.461 \\
\hline Microstella norvegica & 0.988 & 0.154 \\
\hline Acartia spinicauda & 0.984 & 0.179 \\
\hline Acartia copepodids & 0.967 & -0.255 \\
\hline Eucalanus elongatus & 0.091 & -0.996 \\
\hline Labidocera acuta & 0.999 & -0.033 \\
\hline Oithona similis & 0.907 & 0.421 \\
\hline Oikopleurapava & 0.988 & 0.154 \\
O. dioica & 0.988 & 0.154 \\
\hline Temora turbinata & -0.361 & -0.933 \\
T. discaudata & -0.361 & -0.933 \\
Centropages copepodids & -0.655 & -0.756 \\
Oikopleurasp & -0.997 & 0.073 \\
A. erythreae & -0.536 & -0.844 \\
Oncaea venusta & -0.361 & -0.933 \\
\hline Oithona copepodids & -0.655 & 0.756 \\
Acartia danae & -0.627 & 0.779 \\
Calanopia minor & -0.627 & 0.779 \\
Macrosetellagracilis & -0.627 & 0.779 \\
\hline Paracalanusparvus & -0.627 & 0.779 \\
Nannocalanus minor & -0.627 & 0.779 \\
\hline
\end{tabular}

0.6 could be taken for interpretation (Udayakumar et al., 2009). At Mangalore, PCA extracted two components (hereafter referred to as PC1 and PC2) matrix (Tab. 1), which explains $100 \%$ of total variance (Tab. 2) and they are directly linked with zooplankton grazing predicting the routine $(\mathrm{PC} 1$ ) and opportunistic (seasonal) grazers (PC2). The individual PCA coefficients are presented in Tab. 1. The PC1 explains $56.9 \%$ of the total variance and can be used to distinguish samples located within the extraction areas. In this component, the most notable observation was that the calanoid species viz, $C$. furcatus, $A$. spinicauda, Acartia copepodids, L. acuta, cyclopoids $O$. similis and harpacticoid $M$. norvegica showed positive significant correlation, indicating their preference for sharing the same feeding habitat devoid of competition. But they showed negative correlation with Centropages copepodids, Oikopleura sp, Oithona copepodids, A. danae, C. minor, M. gracilis, P. parvus and N. minor. As stated, Oikopleura sp. are juvenile appendicularian gathered at the surface water to share the phytoplankton grazing along with the dominant copepods. But their population was very well utilized by the highly carnivorous copepods such as $L$. acuta and $O$. similis with a definite prey-predation relation. However, the adult appendicularians have utilized the upwelled phytoplankton spores and available major group of the abundant phytoplankton. The grazing pressure from the positive significant copepod groups discouraged the remaining gathered negatively significant cope-

Tab. 2. Cumulative percentage of PCA extracted components at Mangalore

\begin{tabular}{|c|c|c|c|c|c|c|}
\hline \multicolumn{7}{|c|}{ Total Variance Explained } \\
\hline \multirow{2}{*}{ Component } & \multicolumn{3}{|c|}{ Initial Eigen values } & \multicolumn{3}{|c|}{ Extraction Sums of Squared Loadings } \\
\hline & Total & $\%$ of Variance & Cumulative \% & Total & $\%$ of Variance & Cumulative $\%$ \\
\hline PC 1 & 11.946 & 56.886 & 56.886 & 11.946 & 56.886 & 56.886 \\
\hline PC 2 & 9.054 & 43.114 & 100 & 9.054 & 43.114 & 100 \\
\hline 3 & $1.83 \mathrm{E}-15$ & $8.73 \mathrm{E}-15$ & 100 & & & \\
\hline 4 & $7.02 \mathrm{E}-16$ & $3.35 \mathrm{E}-15$ & 100 & & & \\
\hline 5 & $6.69 \mathrm{E}-16$ & $3.18 \mathrm{E}-15$ & 100 & & & \\
\hline 6 & 4.40E-16 & $2.10 \mathrm{E}-15$ & 100 & & & \\
\hline 7 & $3.69 \mathrm{E}-16$ & $1.76 \mathrm{E}-15$ & 100 & & & \\
\hline 8 & $3.07 \mathrm{E}-16$ & $1.46 \mathrm{E}-15$ & 100 & & & \\
\hline 9 & $2.29 \mathrm{E}-16$ & $1.09 \mathrm{E}-15$ & 100 & & & \\
\hline 10 & $1.81 \mathrm{E}-16$ & 8.64E-16 & 100 & & & \\
\hline 11 & $1.31 \mathrm{E}-16$ & $6.22 \mathrm{E}-16$ & 100 & & & \\
\hline 12 & $1.04 \mathrm{E}-16$ & 4.94E-16 & 100 & & & \\
\hline 13 & $1.42 \mathrm{E}-17$ & $6.77 \mathrm{E}-17$ & 100 & & & \\
\hline 14 & $-3.37 \mathrm{E}-17$ & $-1.61 E-16$ & 100 & & & \\
\hline 15 & $-3.80 \mathrm{E}-17$ & $-1.81 \mathrm{E}-16$ & 100 & & & \\
\hline 16 & $-9.19 \mathrm{E}-17$ & $-4.38 \mathrm{E}-16$ & 100 & & & \\
\hline 17 & $-1.51 \mathrm{E}-16$ & $-7.18 \mathrm{E}-16$ & 100 & & & \\
\hline 18 & $-2.51 \mathrm{E}-16$ & $-1.20 \mathrm{E}-15$ & 100 & & & \\
\hline 19 & $-2.95 \mathrm{E}-16$ & $-1.40 \mathrm{E}-15$ & 100 & & & \\
\hline 20 & $-4.30 \mathrm{E}-16$ & $-2.05 E-15$ & 100 & & & \\
\hline 21 & $-7.09 \mathrm{E}-16$ & $-3.38 \mathrm{E}-15$ & 100 & & & \\
\hline
\end{tabular}


24

pods by way of jerking away from their feeding ground. PC2 represents the grazing of opportunistic invaded copepods along with Oithona copepods which have gathered along with them in search of food. However, the influence and relationship of resident copepod, appendicularian and towards the opportunistic invaders along the M1 showed good homogeneity in the specific situations examined. Using the data bases and statistical interpretation from this study, as well as available literature, we grouped the copepod-appendicularian abundance into two meaningful categories viz, routine and opportunistic grazers of phytoplankton along the Mangalore coast. The appendicularians abundance and food preference concentrates in a water column having high abundance of bacteria, some detritus and phytoplankton (Alldredge, 1976). In contrast with copepods, which have long been considered as the major component of secondary production in the sea, appendicularians use their mucus network to graze on bacteria, small nanoflagellates (Alldredge and Madin, 1982; Deibel and Powell, 1987). As described earlier, the Secchi depth at coastal Mangalore is approximately $0.5 \mathrm{~m}$, due to high turbidity resulting from the upwelling, most likely induced by southwest monsoon and subsequently benthic resting stages of diatom which contribute by seeding the water column, they can influence the standing crop of phytoplankton community (Harnstrom et al., 2007).

Highest concentration of phytoplankton pigments in the current study also confirms the similar upwelling related productivity in addition to river inputs. It could be

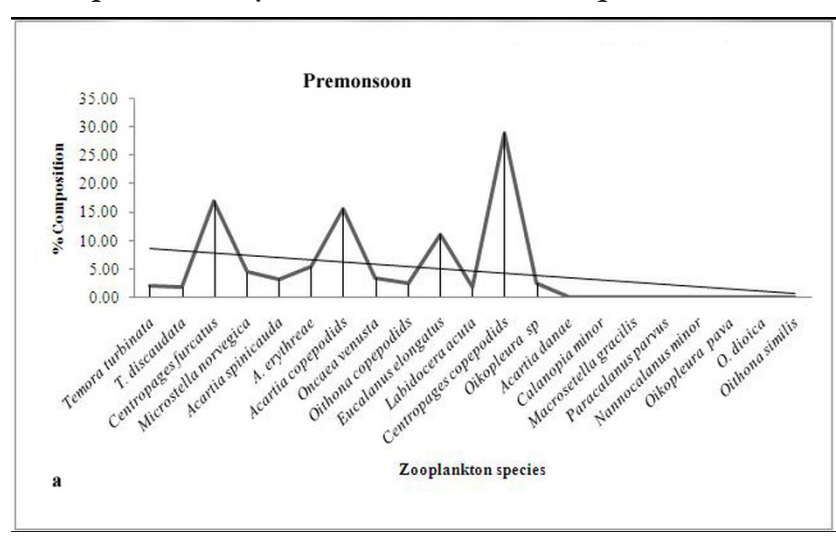

assumed that the copepods together with the juvenile and adult appendicularians aggregated at the chosen study site only for grazing over the upwelled resting stages of diatoms. Earlier findings revealed that appendicularian densities are mostly limited to eutrophic waters and to phytoplankton blooms (Nakamura et al., 1997). As a result, the seasonal competition for food is functioning between copepodids, copepods and appendicularian consisting of juveniles and adults. In addition carnivorous copepods got attracted by the juvenile stages of appendicularians. Analysis of results suggest that changes in the feeding rates in carnivorous copepod ( $L$. acuta and $O$. similis) concentrations of Mangalore coastal waters were not correlated to the juvenile appendicularians (Oikopleura sp,), but were significantly correlated with adult appendicularians in the 0.5 to $2.0 \mathrm{~mm}$ size fraction. Predation of calanoid copepod on appendicularian eggs and young ones in captive condition was well documented (Urrutia et al., 2004). Most of the marine copepods feed on larger cells $(>23 \mu \mathrm{m})$ at high rates, the smaller copepods also grazed at similar rates on nanoplankton (5 to $23 \mu \mathrm{m})$ and picoplankton $(<5 \mu \mathrm{m})$ (Vargas and Gonzalez, 2004). The carnivorous nature of L. acuta and O. similis of the Arabian Sea was stated by Madhupratap (1999). This result tends to indicate a strong feeding bias of copepods towards appendicularians of $<0.5$ $\mathrm{mm}$ size in wild condition along Mangalore coast. However, the in situ study carried out in the coastal waters of Chile reported that the heterotrophic protists constitute a substantial part of the diet of both calanoid (A. tonsa and

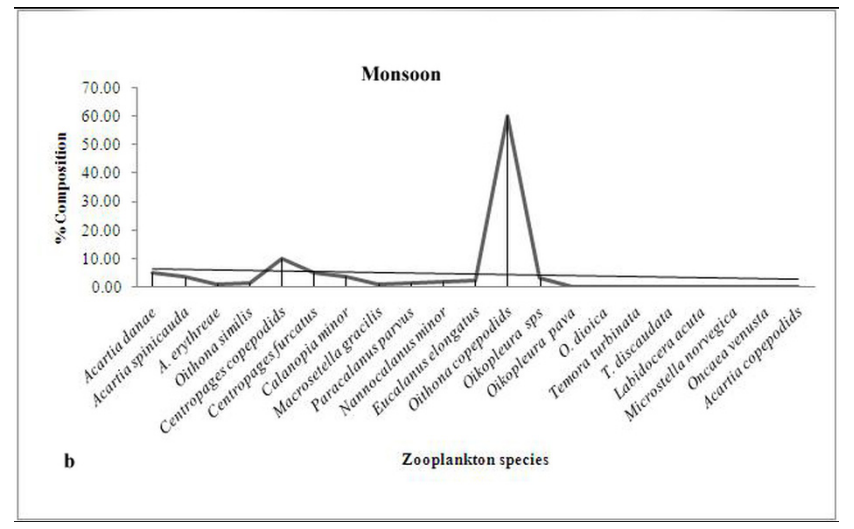

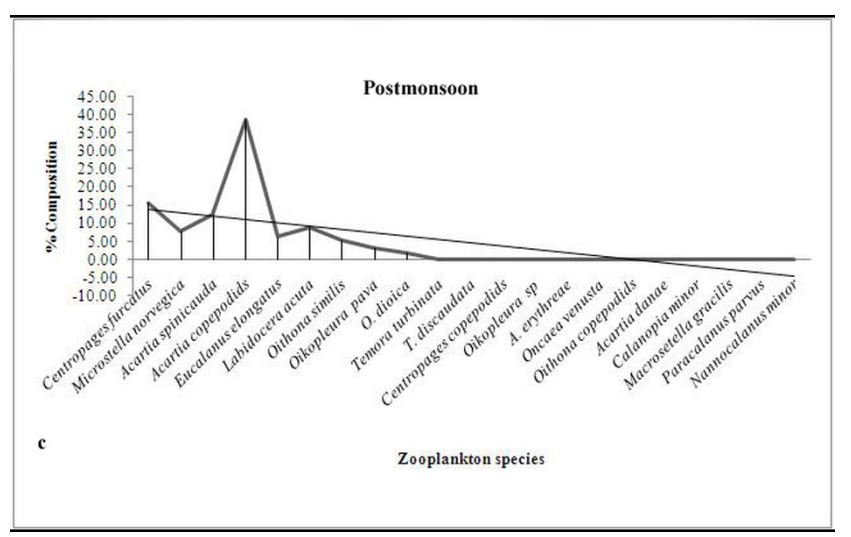

Fig. 3 a, b, c. Species diversity of zooplankton along Mangalore coast during different seasons 
Centropages brachiatus) and cyclopoid (O. similis) (Vargas and Gonzalez, 2004). In fact, our results from Mangalore upwelled coastal waters also showed seasonal abundance of the cyclopoid O. similis and the calanoid genera - Acartia and Centropages. Accordingly the competitive interactions between copepods and appendicularians for phytoplankton feeding sometimes provoke the carnivorous feeding of copepods, when phytoplankton concentration are low and turn them as appendicularian predators, as suggested by Ohman and Runge (1994) in the wild. Their results corroborate with the findings of the present study to provide further evidence of threshold to research perspectives in the field of phytoplankton - appendicularia - copepod - fish food chain along Mangalore coast connected with upwelling and biological productivity. On the whole, the entire final gain reflects in the capture fishery sector and its sustainability.

\section{Conclusions}

There is no previous information on the food chain relationship of phytoplankton-appendicularian-copepodfishes from the coastal upwelling zones of India, especially from the Mangalore coastal waters. Analysis of data for two years (2009 January to 2010 December) in respect of seasonal abundance of copepods and appendicularians suggests the biological productivity and later the statistical interpretation in between their food and feeding relations. It also opens up a new avenue in indicating the commercial fish abundance along Mangalore coastal waters primarily based on continuous monitoring.

\section{Acknowledgements}

We thank The Director, CESS for the facilities provided. We also thank the Ministry of Earth Science, Govt. of India, New Delhi for financial support in the form of a sponsored project Coastal Ocean Monitoring and Prediction System (COMAPS). We are grateful for the assistance in the field from the Masters and Crew members of purse seiners. This paper is a part of the $\mathrm{PhD}$ thesis work of corresponding author registered in Manonmaniam Sundaranar University, India.

\section{References}

Alldredge AL (1976). Field behavior and adaptative strategies of appendicularians (Chordata: Tunicata). Mar Biol 38:29-39.

Alldredge AL, Madin LP (1982). Pelagic tunicates: unique herbivores in the marine plankton. Bio Sci 32:655-663.

Deibel D, Powell CVL (1987). Ultrastructure of the pharyngeal filter of the appendicularian Oikopleura vanhoeffeni: implications for particle size selection and fluid mechanics. Mar Ecol Prog Ser 35:243-250.

Duffy-Anderson JT, Bailey KM, Ciannelli L, Cury P, Belgrano A, Stenceth NC (2005). Phase transitions in marine fish re- cruitment process. Ecol Complex 2:205-218.

Grasshoff K, Kremling K Ehrhardt M (1999). Methods of Seawater Analysis, Wiley VCH Verlag, Germany, 600 p.

Harnstrom K, Godhe A, Saravanan V, Karunasagar I, Holm R (2007). Tropical phytoplankton community development in mesocosms inoculated with different life stages. Mar Ecol Prog Ser 346:75-88.

Harnstrom K, Karunasagar I, Godhe A (2009). Phytoplankton species assemblages and their relationship to hydrographic factors - a study at the old port in Mangalore, coastal Arabian Sea. Ind J Mar Sci 38:224-234.

Jahnke RA, Shimmield GB (1995). Particle flux and its conversion to the sediment record: coastal ocean upwelling systems, 83-100 p. In: Summerhayes CP, Emeis KC, Angel MV, Smith RL, Zeitzschel B (Eds.). Upwelling in the Ocean: modern processes and ancient records, John Wiley and Sons, New York.

Kasturirangan LR (1963). Key to the identification of the more common pelagic copepods of the Indian coastal waters. INCOR, C S I R Publications 2, New Delhi, 128 p.

Kleppel GS, Holliday DV, Pieper RE (1991). Trophic interactions between copepods and microplankton: a question about the role of diatoms. Limnol Oceanogr 36:193-198.

Levinsen H, Turner JT, Nielsen TG, Hansen BW (2000). On the trophic coupling between protists and copepods in arctic marine ecosystems. Mar Ecol Prog Ser 204:65-77.

Madhupratap M (1999). Free-living copepods of the Arabian Sea: Distributions and research perspectives. Ind J Mar Sci 28:146-149.

Madhupratap M, Nair KNV, Gopalakrishnan TC, Haridas P, Nair KKC, Venugopal P, Gauns M (2001). Arabian Sea Oceanography and fisheries of the west coast of India. Curr Sci 81:355-361.

Nakamura Y, Suzuki K, Suzuki S, Hiromi J (1997). Production of Oikopleura dioica (Appendicularia) following a picoplankton 'bloom' in a eutrophic coastal area. J Plankton Res 19:113-124.

Ohman MD, Hirche HJ (2001). Density-dependent mortality in an oceanic copepod population. Nature 412:638-641.

Ohman MD, Runge JA (1994). Sustained fecundity when phytoplankton resources are in short supply: omnivory by Calanus finmarchicus in the Gulf of St. Lawrence. Limnol Oceanogr 39:21-36.

Paffenhofer GA (1998). On the relation of structure, perception and activity in marine planktonic copepods. J Mari Syst 15:457-473.

Peinert R, Bodungen B, Smetacek V (1989). Food web structure and loss rate, 35-48 p. In: Berger WH, Smetacek VS, Wefer G (Eds.). Productivity of the ocean: present and past, John Wiley and Sons, New York.

Piatt JF, Anderson P (1996). Response of common murres to the Exxon Valdez oil spill and long-term changes in the Gulf of Alaska marine ecosystem. Am Fish Soc Symp 18:720-737. 
26

Pierce RW, Turner JT (1992). Ecology of planktonic ciliates in marine food webs. Rev Aquat Sci 6:139-181.

Sibel Y (2006). Analysis of the Zooplankton Community by the Shannon-Weaver Index in Kesikkopru Dam Lake, Turkey. Tarim Bilim Derg 12:216-220.

Strictland JDH, Parsons TR (1972). A Practical Handbook of Seawater Analysis. Bulletin, $2^{\text {nd }}$ Ed Fisheries Research Board of Canada, Ottawa, Canada, 310 p.

Udayakumar P, Abhilash PP, Ouseph PP (2009). Assessment of Water Quality Using Principal Component Analysis- A Case Study of the Mangalore Coastal Region, India. J Environ Sci Eng 51:179-186.

Urrutia AL, Roger PH, Smith T (2004). Predation by calanoid copepods on the appendicularian Oikopleura dioica. Limnol Oceanogr 49:303-307.
Vargas CA, Gonzalez HE (2004). Plankton community structure and carbon cycling in a coastal upwelling system. I. Bacteria, microprotozoans and phytoplankton in the diet of copepods and appendicularians. Aquat Microb Ecol 34:151164.

Vargas CA, Tönnesson K, Sell A, Maar M, Moller EF, Zervoudaki T, Giannakourou A, Christou E, Satapoomin S, Petersen JK, Nielsen NG, Tiselius P (2002). Importance of copepods versus appendicularians in vertical carbon fluxes in a Swedish fjord. Mar Ecol Prog Ser 241:125-138.

Venkataraman K, Wafar M (2005). Coastal and marine biodiversity of India. Ind J Mar Sci 34:57-75.

Verlecar XN, Desai SR, Sarkar A, Dalal SG (2006). Biological indicators in relation to coastal pollution along Karnataka coast, India. Water Res 40:3304-3312. 